\title{
Longer decomposition process and the influence on Coleoptera fauna associated with carcasses
}

\author{
Mise, KM.*, Martins, CBC., Köb, EL. and Almeida, LM. \\ Laboratório de Sistemática e Bioecologia de Coleoptera, Departamento de Zoologia, \\ Universidade Federal do Paraná - UFPR, \\ Rua Coronel Francisco H. dos Santos, s/n, Jardim das Américas, \\ CP 19020, CEP 81531-980, Curitiba, PR, Brazil \\ *e-mail: klebermise@yahoo.com.br
}

Received April 25, 2008 - Accepted July 28, 2008 - Distributed November 30, 2008

\begin{abstract}
Cadavers are colonized by different species of animals, mainly insects such as flies and beetles (Kocarek, 2003). The succession of these insects and the time they live on the carcasses is used to determine in which circumstances death occurred and to estimate the postmortem interval (Catts and Goff, 1992). The Coleoptera order is the richest and most diverse of the Insecta class with 350,000 species, corresponding to nearly $40 \%$ of all insects (Grimaldi and Engel, 2005). This high diversity is present in carcasses as well, Coleoptera being the richest order of importance in forensic entomology. The present paper attempts to better understand the Coleoptera fauna on carcasses, as well as its changes through time. The experiment took place in a fragment of Araucaria forest in the campus of the Universidade Federal do Paraná, in Curitiba, Paraná, Brazil. The samplings were taken from April $18^{\text {th }}$ to September $5^{\text {th }}, 2005$. The average temperature ranged between 15 and $23{ }^{\circ} \mathrm{C}$ and the relative humidity between 72 and $92 \%$. The animal used was a $14 \mathrm{~kg}$ Sus scrofa Linnaeus, 1758 (domestic pig) killed by a stab in the heart. The carcass was put inside
\end{abstract}

an iron cage with $2.5 \mathrm{~cm}$ openings, to avoid the entry of vertebrates. The insects were collected actively and daily in a metallic tray positioned below the cage. There were also passive samplings using pitfall traps with $4 \%$ formalin, checked every 14 days and a modified Shannon trap (Mise et al., 2007), the top of which was pyramid-like, having a pot filled with $70 \%$ ethanol connected to its apex, checked daily.

The decompositional process was divided according to the classification of Bornemissza (1957), and was, in days, as follows: initial decay (2), putrefaction (11), black putrefaction (18), butyric fermentation (34) and dry decay (75)

The following references were used for the Coleoptera identification: Booth et al. (1990), Borror et al. (1992) and White (1983).

Twenty families of Coleoptera were collected, of which 12 are usually associated with carcasses (Smith, 1986), the others being considered accidental because of their feeding habits (Table 1). The main Coleoptera families of forensic importance and their abundance were: Staphylinidae $(1,178)$, Silphidae (183), Histeridae

Table 1. Succession of Coleoptera families in pig carcasses in Curitiba, Paraná. The darker colors mean a higher abundance every 14 days.

\begin{tabular}{|c|c|c|c|c|c|c|c|c|c|c|}
\hline Family/days & $\begin{array}{c}04 / 18 \\
\text { to } \\
05 / 1 \\
\end{array}$ & $\begin{array}{c}05 / 2 \\
\text { to } \\
05 / 15\end{array}$ & $\begin{array}{c}05 / 16 \\
\text { to } \\
05 / 29 \\
\end{array}$ & $\begin{array}{c}05 / 30 \\
\text { to } \\
06 / 12 \\
\end{array}$ & $\begin{array}{c}06 / 13 \\
\text { to } \\
06 / 26 \\
\end{array}$ & $\begin{array}{c}06 / 27 \\
\text { to } \\
07 / 10 \\
\end{array}$ & $\begin{array}{c}07 / 11 \\
\text { to } \\
07 / 24 \\
\end{array}$ & $\begin{array}{c}07 / 25 \\
\text { to } \\
08 / 07\end{array}$ & $\begin{array}{c}08 / 08 \\
\text { to } \\
08 / 21 \\
\end{array}$ & $\begin{array}{c}08 / 22 \\
\text { to } \\
09 / 5 \\
\end{array}$ \\
\hline \multicolumn{11}{|l|}{ ANTHICIDAE } \\
\hline \multicolumn{11}{|l|}{ CARABIDAE } \\
\hline \multicolumn{11}{|l|}{ CLERIDAE } \\
\hline \multicolumn{11}{|l|}{ DERMESTIDAE } \\
\hline \multicolumn{11}{|l|}{ HISTERIDAE } \\
\hline \multicolumn{11}{|l|}{ LEIODIDAE } \\
\hline \multicolumn{11}{|l|}{ NITIDULIDAE } \\
\hline \multicolumn{11}{|l|}{ SCARABAEIDAE } \\
\hline \multicolumn{11}{|l|}{ SILPHIDAE } \\
\hline \multicolumn{11}{|l|}{ STAPHYLINIDAE } \\
\hline TENEBRIONIDAE & & & & & & & & & & \\
\hline TROGIDAE & & & & & & & & & & \\
\hline
\end{tabular}

Light gray - 1 to 5 specimens; Dark gray - 6 to 11 specimens; and Black - 12 or more specimens. 
(18), Nitidulidae (13), Trogidae (8), Cleridae (4), Dermestidae (4), Scarabaeidae (3), Anthicidae (2), Carabidae (2), Tenebrionidae (2) and Leiodidae (1), totalling 1,418 specimens.

In the entomological succession, there were many recurring taxa that arrived to and departed from the carcass several times (Table 1). The succession differed from other studies at family level. Monteiro-Filho and Penereiro (1987) and Cruz and Vasconcelos (2006) found five and eight families, respectively, mostly due to regional and methodological differences. In relation to the many recurrent taxa, the present methodology of sampling attempted to lessen interference in decomposition, by not manipulating the carcass. If the samplings were made directly on the carcass it could prove that these taxa occur in a single period of time.

It was expected that a longer decomposition process would lead to an increase in the number of species found in the dry remains, such as Dermestidae, that feed primarily on dried skin and Cleridae, that prey upon dermestids (Catts and Haskell, 1990). Surprisingly, in this study a longer decomposition process did not interfere with the Coleoptera fauna. The species of Staphylinidae, for example, were captured in great numbers throughout the experiment, even in advanced decomposition stages. In this experiment the dominant species, Aleochara sp., as well as most Staphylinidae, are predators attracted by fly larvae. Additionally, the species of the genus Aleochara is known to parasite Diptera puparium (Ashe, 2002).

The species of Silphidae occurred in great numbers from the beginning of the samplings, but depleted after 98 days and ceased to occur after 126 days. There were two species of this family, Oxelytrum discicolle (Brullé, 1840) and O. erythrurum (Blanchard, 1840), which feed on large Diptera larvae, which do not occur after 126 days.

The present study had similar results with those of Mise et al. (2007), regarding the three most abundant families, but the dry remains stage was not reached in the latter. This means that a longer decomposition process does not raise significantly the abundance of families known to be found in the dry remains stage, such as Dermestidae and Cleridae, as in both experiments there was a reduced number of them. This could be explained by the high humidity that slows decomposition, reducing the presence of some species. Therefore different regions have implications for forensic studies indicating that Dermestidae and Cleridae are probably not good forensic indicators, disagreeing with Kulshrestha and
Satpathy (2001), who considered them as evidence on corpses.

Acknowledgements - Contribution no. 1755, Departament of Zoology, Federal University of Paraná, UFPR.

\section{References}

ASHE, JS., 2002. Aleocharinae. In: NAVARRETEHEREDIA, JL., NEWTON, AF., THAYER, MK., ASHE, JS and CHANDLER, DS. Guía ilustrada para los gêneros de Staphylinidae (Coleoptera) de México. Guadalajara: Universidad de Guadalajara y CONABIO. 401 p.

BOOTH, RG., COX, ML. and MADGE, RB., 1990. 3. Coleoptera IIE. Guides to insects of importance to man. Cambridge: Cambridge University Press. 384 p.

BORNEMISSZA, GF., 1957. An analysis of arthropod succession in carrion and the effect of its decomposition on the soil fauna. Aust. j. zool., vol. 5, no. 4, p. 1-12.

BORROR, DJ., TRIPLEHORN, CA. and JOHNSON, NF., 1992. An Introduction to the study of insects. New York: Saunders College Publishing. 875 p.

CATTS, EP. and HASKELL, NE., 1990. Entomology \& Death: A procedural guide. Clemson: Joyce's Print Shop. 182 p.

CATTS, EP. and GOFF, ML., 1992. Forensic entomology in criminal investigations. Ann. rev. entomol., vol. 37, p. 253-272.

CRUZ, TM. and VASCONCELOS, SD., 2006. Entomofauna de solo associada à decomposição de carcaça de suíno em um fragmento de mata atlântica de Pernambuco, Brasil. Biociências (Porto Alegre), vol. 14, no. 2, p. 193-201.

GRIMALDI, D. and ENGEL, MS., 2005. Evolution of the Insects. Cambridge: Cambridge University Press. 755 p.

KOCÁREK, P., 2003. Decomposition and Coleoptera sucession on exposed carrion of small mammal in Opava, the Czech Republic. Eur. j. soil biol., vol. 39, p. 31-45.

KULSHRESTHA, P. and SATPATHY, DK., 2001. Use of beetles in forensic entomology. Forensic sci. int., vol. 120, no. 1-2, p. 15-17.

MISE, KM., ALMEIDA, LM. and MOURA, MO., 2007. Levantamento da fauna de Coleoptera que habita a carcaça de Sus scrofa L., em Curitiba, Paraná. Rev. bras. entomol., vol. 51, no. 3 , p. $358-368$.

MONTEIRO-FILHO, ELA. and PENEREIRO, JL., 1987. Estudo da decomposição e sucessão sobre uma carcaça animal numa área do estado de São Paulo, Brasil. Rev. bras. biol., vol. 47 , no. 3, p. 289-295.

WHITE, RE., 1983. A field guide to the beetles of North America. The Peterson field guide series 29. Boston: Houghton Mifflin Company. 368 p. 